\title{
Intertextual Strategy of the Narrator of the Second Epistle of Peter in the Catalogue of Virtues (1:5-7)
}

\author{
KALINA WOJCIECHOWSKA \\ Christian Theological Academy in Warsaw \\ kalinawojciechowska@icloud.com, ORCID: 0000-0002-0028-6905
}

\section{MARIUSZ ROSIK}

Pontifical Faculty of Theology in Wrocław

mrosik@pnet.pl, ORCID: 0000-0002-1943-8649

\begin{abstract}
The Second Epistle of Peter is one of the least studied texts of the New Testament. It is usually compared with 1 Peter and/or Jude and indeed shows some similarities and some differences with these texts. But little attention is paid to the originality of 2 Peter both in its interpretation of texts from the Jewish tradition and in the application of intertextual strategies to elements of Greek philosophy. 2 Pet 1:5-7 is undoubtedly one of the most Hellenized passages of the epistle. Not only did the narrator use a hierarchical catalog of virtues popular in Greek literature, but also terms that are commonly

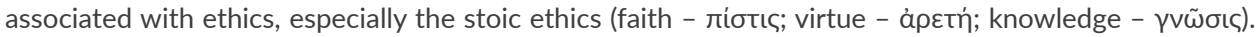
This article aims to present the manner in which the narrator in 2 Pet 1:5-7 enters into dialogue with Greek ethical texts and how he transforms, innovates, and reinterprets these texts. In other words, what intertextual strategy he uses.
\end{abstract}

Keywords: Second Letter of Peter, hypertextualism, intertextuality, catalog of virtues, stoic ethics, faith, knowledge, virtue, 2 Pet 1:5-7

According to Michał Głowiński, intertextuality can be generally defined as a case of adoption or imitation, accompanied by a differentiating element, when a certain interplay between texts is established and the element of dialogism is present. ${ }^{1}$ Gérard Genette refers to the relationship between the later text or hypertext and the earlier, underlying text or hypotext as hypertextuality. ${ }^{2}$ As these two descriptions refer to the same phenomenon, it has been decided to apply to it the term intertextuality, while the analysed text and the source text will be referred to as hypertext and hypotext respectively.

Głowiński, "O intertekstualności," 79.

Genette, Palimpsesty, 11. 
This article consists of two parts. ${ }^{3}$ The first is devoted to the hypotext. It includes a brief overview of Greek texts which catalogue virtues. Initially the arrangement of items in those aretological lists was non-hierarchical but over time started forming a chain in which each subsequent link is rooted in the previous one. The narrator of 2 Peter adopts this form, but he arranges the links of his chain in a different order than the Greek philosophers. Thus, the second part of the article is devoted to analysing this order, accompanied by a change in the meanings of concepts that make up the links. These analyses will be used to draw conclusions on the nature of the formal and semantic transformations that were introduced. Due to scarcity of space, out of the eight elements of Peter's sorites, only the first three have been selected for detailed analysis, as they can be considered representative and sufficient to determine

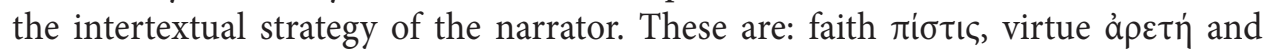
knowledge $\gamma \nu \tilde{\omega} \sigma ı c$. It is also significant that they are interpreted already at the beginning of the epistle (2 Pet 1-3), so it is possible to trace how this interpretation was later taken into account in Peter's aretological catalogue.

\section{Catalogues of Virtues in Greek Literature}

\subsection{Non-hierarchical Catalogues of Virtues}

Catalogues of virtues (and vices) were common in Greek literature. The form itself dates back to the Homeric era and originally was not associated with moral philosophy. ${ }^{4}$ It appears in satire, for example in Aristophanes' The Frogs $(5,200)$, where it serves to stereotype certain behaviours. In this case Charon forces Dionysus to get into a boat and row; Dionysus wriggles out of this by using a list of qualities that prevent him from rowing: "Now how will I manage that? I'm green, a landlubber, no

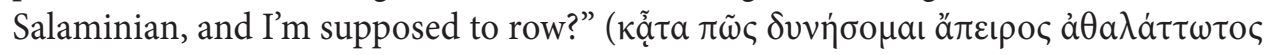

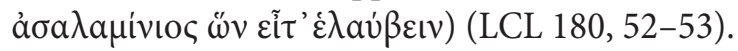

Over time, catalogues of virtues and vices increasingly appear in philosophical literature. One of them is presented by Aristotle in his Rhetoric (1366b): "Virtue, it would seem, is a faculty of providing and preserving good things, a faculty productive of many and great benefits, in fact, of all things in all cases. The components of virtue are justice, courage, temperance, magnificence, magnanimity, lib-

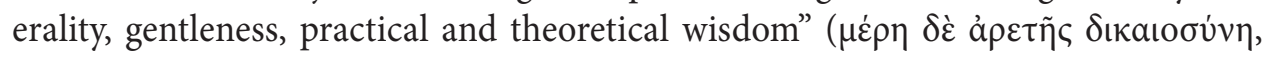

3 The article uses material from a paper currently being prepared for publication Wojciechowska - Rosik, Głoszac przyjście Pana. Komentarz strukturalny do Drugiego Listu św. Piotra [Proclaiming the Coming of the Lord. A Structural Commentary to the Second Epistle of St. Peter], to be published by the Christian Academy of Theology in Warsaw.

4 Charles, "The Language," 57. 


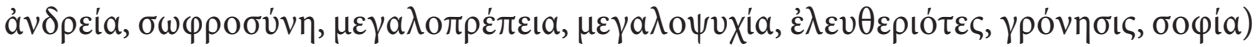
(LCL 193, 88-89). Each virtue is then discussed in more detail.

Among the virtues described by Aristotle there are those that in the ancient world would be referred to as cardinal virtues - fortitude, justice, temperance and prudence, which stand for certain actions. Menander (Rethor II, 373,21; LCL 539, 150-151) encourages us to see these virtues in every action and its evaluation: "Everywhere divide the deeds you are going to praise according to the four virtues (courage, justice, moderation and intelligence), and consider to which virtues the deeds belong and whether some deeds in war and in peace share a single virtue [...]." Also Quintilian links the cardinal virtues with actions: "In other cases, it has seemed better to split up the encomium into the various virtues-courage, justice, self-control and so on-and assign to each the acts performed in accordance with each" (Institutio Oratoria III, 7,15; LCL 125, 108-109). Slightly different virtues are mentioned in one first-century inscription from Asia Minor, which praises Herostratos, son of Dorkalion, and attributes to him the following virtues, which overlap in part with those given by the author of 2 Peter: "being a good man distinguished in faith [ $\pi i \sigma \tau \varepsilon l$,$] and$

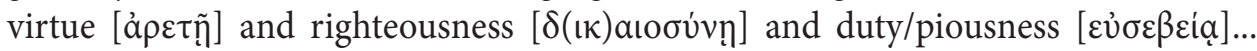

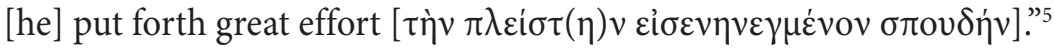

It seems that in Hellenistic times such catalogues - largely accompanying Stoic philosophical and ethical reflection - were already very common in many circles. As J. Daryl Charles notes, this was due to a turn away from purely theoretical considerations to the practical dimension. Thus the lists would be in use on their own i.e. without intricate, detailed philosophical commentaries. Speakers were eager to use them, all the more so because they fulfilled epideictic functions in the speeches i.e. their presentation was supposed to arouse appreciation or dislike and embarrassment in the audience. ${ }^{6}$ From there it was only a step away from using them in parenetic literature.

Aretological catalogues also became popular among Jews especially those strongly associated with the Hellenistic culture. Thus, for example, Philo of Alexandria in De Sacrificiis Abeli et Caini 5, 26-27.32 lists of several dozen virtues and vices. He begins with a long list of feminine qualities, starting with external appearance, movement and clothing:

her person and her modesty alike without false colouring, her moral nature free from guile, her conduct from stain, her will from craft, her speech from falsehood, reflecting faithfully the honesty of her thoughts. Her carriage was unaffected, her movements quiet, her clothing plain, her adornment that of good sense and virtue, which is more precious

5 Danker, Benefactor, 460; Green, Jude and 2 Peter, 593; on the similarities of this inscription and 2 Pet 1:5-7 see Charles, "Language," 65-66.

6 Charles, "Language," 57. 
than gold. And in her company came piety, holiness, truth, justice, religion, fidelity to oaths and bonds, righteousness, equity, fellow-feeling, self-control, temperance, orderliness, continence, meekness, frugality, contentment, modesty, a quiet temper, courage, nobility of spirit, good judgement, foresight, good sense, attentiveness, desire for amendment, cheerfulness, kindness, gentleness, mildness, humanity, high-mindedness, blessedness, goodness (LCL 227, 112-113).

The second list (De Sacrificiis Abeli et Caini 5, 32) enumerates the vices of a man who, before indulging in pleasure, will be

unscrupulous, [...], braggart, impudent, seditious. conceited, cross-tempered, disorderly, stubborn, unsociable, impious, mean, intractable, unholy, envious, lawless, wavering, [...], troublesome, unstable, quarrelsome, passionate, [...], slanderous, headstrong, profane, vainglorious, coarse, accursed, deceitful, impatient of rebuke, a buffoon cheating, [...], aimless, reckless, murder-stained, ignorant, [...], low-minded, stupid, [...], unjust, beastlike, [faithless], inequitable, slavish, disobedient, unfriendly, cowardly, unruly, irreconcilable, [...], a swindler, implacable. [...], dissembling, covetous, shame-working mischievous, $[\ldots]$, without friend, immoderate, skulking, without home, [...], double-minded, suspicious, evil-minded, double-tongued, faithless, [...], stubborn, [...], garrulous, rascally, a pessimist, a babbler, incorrigible, lacrimose, [...], a flatterer, [...], maniacal, [...], fickle, feud-loving, [...], a glory-hunter, [...], violent-tempered, ill-managing, unregulated, ill-conditioned, stiff-necked, [...], sulle, womanish, easily led, quick to wrath, [...], timorous, a scoffer, [...], a glutton [...] (LCL 227, 117-119).

The longer a list, the more difficult it is to arrange its elements in order. This is why both the lists made by Greek philosophers and the lists made by Jewish writers writing in Greek give the impression of being unsystematic, and the order of items listed seems rather random ${ }^{7}$ or at least not hierarchical.

\subsection{Hierarchical Catalogues of Virtues}

However, in addition to catalogues in which individual items remain non-hierarchical or are regarded as egalitarian, Greek literature produced catalogues drawn up according to a rhetorical principle called sorites (chain). A sorites is a type of syllogism with more than two premises. These premises form individual links of a chain, which ends with a conclusion. They are most often formed by sentences in which the predicate of the preceding sentence becomes the subject of the following sentence. In the last link, there is usually a fusion, typical of syllogisms, of the subject of the first

7 Charles, "Language," 58. 
sentence with the predicate of the penultimate sentence. ${ }^{8}$ Such a figure already appears in the Iliad $(2,100-108)$, although it did not concern virtues and vices, but the origin of Agamemnon's sceptre:

Then among them lord Agamemnon stood up, holding in his hands the scepter which Hephaestus had toiled over making. Hephaestus gave it to lord Zeus, son of Cronos, and Zeus gave it to the messenger Argeïphontes; and Hermes, the lord, gave it to Pelops, driver of horses, and Pelops in turn gave it to Atreus, shepherd of men; and Atreus at his death left it to Thyestes, rich in flocks, and Thyestes again left it to Agamemnon to carry, to be lord of many isles and of all Argos (LCL 170, 68-69).

As regards virtues, a classical sorites with a final syllogism is applied by Seneca in Epistulae Morales $(85,2)$ : "He that possesses prudence is also self-restrained; he that possesses self-restraint is also unwavering; he that is unwavering is unperturbed; he that is unperturbed is free from sadness; he that is free from sadness is happy. Therefore, the prudent man is happy, and prudence is sufficient to constitute the happy life" (LCL 76, 286-287). Cicero, in his work On the Laws (I, 7,23), develops the following links, beginning, not coincidentally, with reason:

[...] he is the only one among so many different kinds and varieties of living beings who has a share in reason and thought, while all the rest are deprived of it. But what is more divine, I will not say in man only, but in all heaven and earth, than reason? And reason, when it is full grown and perfected, is rightly called wisdom. Therefore, since there is nothing better than reason, and since it exists both in man and God, the first common possession of man and God is reason. But those who have reason in common must also have right reason in common. And since right reason is Law, we must believe that men have Law also in common with the gods. Further, those who share Law must also share Justice; and those who share these are to be regarded as members of the same commonwealth. If indeed they obey the same authorities and powers, this is true in a far greater degree; but as a matter of fact they do obey this celestial system, the divine mind, and the God of transcendent power (LCL 213, 321.323).

A sorites can also be found in LXX. In Wis 6:17-20 wisdom is described as a series of sequential and logically derived links: "For the first step toward Wisdom is an earnest desire for discipline; then, care for discipline is love of her; love means the keeping of her laws; To observe her laws is the basis for incorruptibility; and incorruptibility makes one close to God; thus the desire for Wisdom leads to a kingdom." It is apparent that the lists in all these examples are progressive, successive links in the chain lead to a syllogistic conclusion and/or culmination, to the highest

Definition by Mirosław Korolko (Sztuka retoryki, 88); cf. Green, Jude and 2 Peter, 598. 
item in the hierarchy of values or the so-called summum bonum. It can also be noted that the first link of the sorites quoted above is related to reason (Cicero), knowledge, wisdom (Book of Wisdom), discernment, prudence (Seneca). This is undoubtedly connected with the ancient ideal of morality, which was not at all universal. It was believed to be accessible only to the wealthy and educated. ${ }^{9}$ For virtues and ethical conduct resulting from them were considered to be the fruit of reason ( $\lambda$ ójos) and knowledge $(\gamma \nu \tilde{\omega} \sigma \iota \varsigma)$. Not everyone had the ability (à $\lambda$ oүía) and acquired adequate knowledge (ä $\gamma v o r \alpha)$ to recognize virtues, and not everyone had the opportunity, especially the financial security, to practice them. ${ }^{10}$

\section{Adaptation of a Sorites in 2 Peter}

In presenting his catalogue of virtues, the author of 2 Peter draws from Greek models, and at the same time enters into a dialogue, or even a polemic, with the most popular models of sorites. ${ }^{11}$ What he undoubtedly drew from hypotexts is the hierarchical arrangement of virtues, which appear in a non-accidental, strictly defined

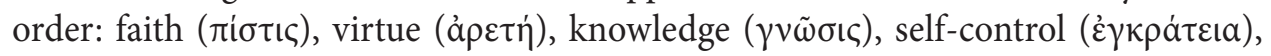

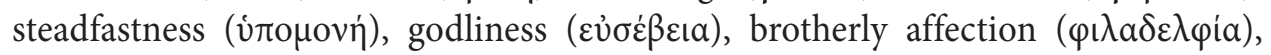
love [of one's neighbour] (å $\gamma \alpha \dot{\alpha} \pi \eta)$. He therefore saw faith as the source of all virtues, and love as the summum bonum.

\subsection{Peter 1:5-7 as a Sorites}

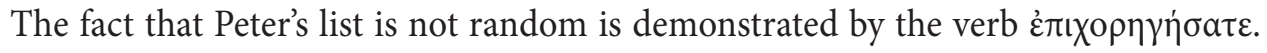
Its basic meaning is "to provide," "to give," "to take care of," "to equip." This meaning derives from antiquity and refers to the Athenian custom of having a choir perform at various ceremonies. It implies a double aspect related to these performances: firstly, "to provide," "to deliver" the choir itself to the festivities; secondly, "to take care," "to provide" the choir with the means of subsistence during the festivities. ${ }^{12}$ Over

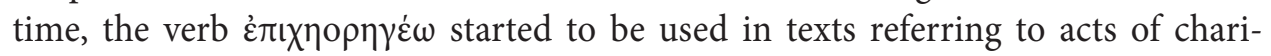
ty, generosity, providing something at one's own expense. It is used in this context, among others, by Diogenes Laërtius in Lives and Opinions of Eminent Philosophers $(\mathrm{V}, 4,67)$ when he speaks of Lycon: „He was esteemed beyond all other philosophers by Eumenes and Attalus, who also did him very great service" (LCL 184, 520-521).

\footnotetext{
Green, Jude and 2 Peter, 594.

Charles, "Language," 59.

See the large monograph on this topic: Charles, Virtue Amidst Vice.

Kelly, Commentary, 306.
} 
In the LXX the verb occurs in a non-compound form as $\chi 0 \rho \eta \gamma \dot{\varepsilon} \omega$ and also means to "supply," "give," "deliver" (1 Kgs 4:7; 5:1; Jdt 12:2; 1 Macc 14:10; 2 Macc 3:3; 4:49; 9:16; 3 Macc 6:30.40; 7:18). This meaning is also known to New Testament writers, but in the New Testament $\dot{\varepsilon} \pi \iota \chi \rho \rho \gamma \dot{\varepsilon} \omega$ appears primarily in texts referring to God's generous, abundant gifts - 2 Cor 9:10; supplying the Spirit - Gal 3:5, or nourishing of all the members of the body (the Church) by the head (Christ) - Col 2:19, and not in relation to human actions.

There may be some problems translating the entire phrase that introduces Peter's list of virtues, and then the subsequent links of the sorites where the prepo-

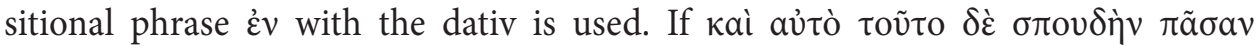
$\pi \alpha \rho \varepsilon ı \sigma \varepsilon v \dot{\varepsilon} \gamma \kappa \alpha \nu \tau \varepsilon \varsigma \dot{\varepsilon} \pi \imath \chi \rho \eta \eta \dot{\gamma} \sigma \alpha \tau \varepsilon$ were to be translated as "And that is why you should make every effort to supply/provide virtue $Y$ to virtue X" or as the most common variant of translation "And that is why you should make every effort to add $Y$ to $\mathrm{X} .{ }^{\prime 13}$ then the progressive nature of the chain and rootedness of each successive link (virtue) in the preceding link (virtue) would not be made explicit enough. ${ }^{14}$ This can also create the erroneous impression that faith - being God's gift, as the narrator emphasises as early as in 1:1 - is insufficient and that something must be added to it. Perhaps the best translation would be a periphrasis: "And that is why you should strive with all your might/zealously to ensure that $Y$ develops through/thanks to X." It would also convey the causal or instrumental meaning of the prepositional phrase $\dot{\varepsilon} v$ with the dative, which forms the individual links of the Petrine chain.

\subsection{Hierarchy of Links in the Chain}

As already noted, most classical sorites or shorter catalogues of virtues begin by emphasising the role of reason, knowledge, and often the wisdom that stems from them. ${ }^{15}$ This meant that not everyone was capable of recognising virtues let alone

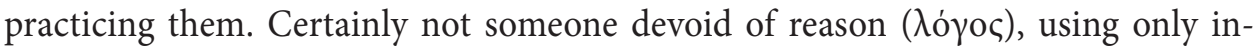
stinct like irrational (å $\lambda \circ \gamma \alpha$ ) animals (cf. 2 Pet 2:12). In order to recognise virtues, one needed to acquire knowledge/insight ( $\gamma \nu \tilde{\omega} \sigma \iota \varsigma)$, which was attainable by the few. This means that the ideal of morality propagated by the Greek philosophers was an elitist one. The narrator of 2 Peter seems to disagree with this take on the realisa-

13 NKJV: "giving all diligence, add to your faith virtue"; NIV: "make every effort to add to your faith goodness"; NIRV: "So you should try very hard to add goodness to your faith"; ESV: "Make every effort to supplement your faith with virtue"; RSV: "make every effort to supplement your faith with virtue."

14 Charles, Jude and 2 Peter, 58. Differently, Richard Bauckham (Jude, 2 Peter, 185), who argues that the order of the virtues in 2 Peter is quite random, and that the whole list is based on a philosophical ethic popular in antiquity, probably Stoic. Significance may possibly be attached to the beginning of this list, where "faith" appears, and to its end, where "love" appears.

15 Mickiewicz, List świętego Judy, 226. 
tion of ideal aretological and axiological models. He does so on two levels - a formal (compositional) and a semantic one.

At the compositional level, the polemic is manifested by giving primacy to faith, from which the concept of virtue is only derived. The third quality Peter mentions is knowledge, which, contrary to Greek philosophers, he derives from virtue and not vice versa. On the basis of the knowledge possessed, temperance/self-control can be practiced, and they in turn become a direct source of steadfastness. Steadfastness leads to godliness, which Peter had already described when he stated that every believer was (most probably at baptism) equipped with everything necessary for a godly life (cf. 2 Pet 1:3). The sequence of further items of the sorites allows us to conclude that godliness is understood here not only as a relationship and responsibility towards God, but also as a relationship and responsibility towards people. Therefore, it represents, as it were, a link between individual virtues/qualities and those are of communitarian significance. Therefore, godliness understood also as an attitude towards members of the community can become a direct source of brotherly love. The narrator points to love as the summum bonum. It seems that he understands it as a practical action towards all his neighbours, not only those who are considered brothers.

A polemical attitude towards the Greek tradition is suggested by the summary of the sorites in 1:8, which contains a somewhat sarcastic reference to the primacy of knowledge/insight in Greek aretological chains. One can guess that knowledge perceived in philosophical, intellectual terms is judged by the narrator as fruitless and idle, although - at least in theory - it gives rise to various virtues. Peter's direction is the opposite - it is virtues rooted in faith and reflecting its practical aspects that lead to true knowledge, true insight, the content, subject (donor) and object of

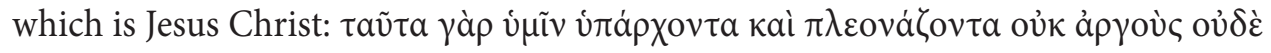

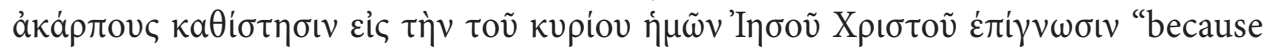
you have them [the previously mentioned sequence of virtues] at your disposal and multiply them, they will not render you useless and unfruitful because of the knowledge of our Lord Jesus Christ."

\subsection{Redefinition of Aretological Concepts}

In order to be able to establish such an aretological hierarchy it was also necessary to introduce semantic changes in the understanding of concepts commonly associated with the Greek sorites. These relate primarily to virtue and knowledge. However, this semantic change begins with Peter's redefinition of the term faith, which also appears in the Greek lists of virtues, although not as the first link. 


\subsubsection{Faith}

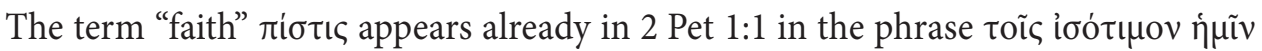

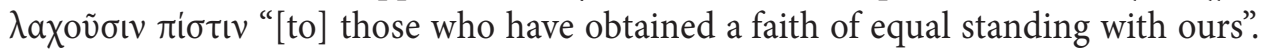
Most likely it serves here as a general reference to revelation based on the Old Testament and the preaching of the apostles. ${ }^{16}$ On the one hand it is cognitive, on the other hand constitutes a personal, existential experience and commitment. ${ }^{17}$ It is therefore not about some already formed and formalised doctrinal system (fides quae), but rather about those experiences that generate personal commitment and specific behaviours (fides qua). This understanding of faith means that everyone who experiences it is equally chosen, privileged, ${ }^{18}$ gifted and equipped by God to live a life according to his will. The close fusion of the existential and practical elements in the concept of $\pi$ í $\tau \iota \varsigma$ is a characteristic strategy of the author of 2 Peter. $^{19}$

The narrator, therefore, makes two things clear to his audience right at the beginning of the epistle. First, faith is a gift; second, it is inclusive and egalitarian. This also significantly affects the understanding of faith in the sorites in 1:5. Placing faith at the forefront, the narrator of the epistle seems to be arguing against the Greek exclusivity associated with knowledge and reason. Unlike knowledge, faith is not acquired through any human effort or ability. It is not merely intellectual in nature, but has above all a practical aspect. This element clearly distinguishes Peter's understanding of aretology from its perception in Greek philosophical systems (especially Stoic), where, as said, reflection on virtue is the result of human reasoning. In Peter's axiological system, faith, which in terms of dignity has the same effects for all, being a divine gift regardless of one's ethnic origin or social and material status, entails further virtues that illustrate its practical dimension. In other words, the virtues listed further in the sorites are in fact manifestations of faith and without it they could not exist.

A certain ethical-parenetic similarity between the premises of Peter's sorites and those of the Greek sorites can be observed here. For in both cases, the first, initial concept - whether it be faith or Hellenistic reason - is manifested in and through behaviours described by the subsequent links. What differs the two systems however is the understanding of faith itself.

In the Greco-Roman world, faith meant above all loyalty and reliability. Gene L. Green ${ }^{20}$ gives examples of this understanding of faith in social relations between a patron who is also a benefactor and a client who is a beneficiary of the patron's actions. In this relationship, loyalty relates primarily to the client, while reliability relates to the patron. On the one hand, the client was in fide, i.e. under the faithful, reliable care of the patron; on the other hand, the patron expected the client to repay

\footnotetext{
Gryglewicz, „Rozwój teologii,” 248-251.

Rosik - Wróbel - Langkammer, Komentarz, 67.

Bauckham, Jude, 2 Peter, 168.

Langkammer, „List św. Judy,” 112.

Green, Jude and 2 Peter, 601.
} 
this care with fide, i.e. loyalty and fidelity. This ideal did not always work. Plautus, for example, in his comedy Menaechmi, or The Twin Brothers (571-582, 587-588) condemns the pathological, fraudulent and corrupt understanding of patronage and client claims:

Everybody wants to have many clients: whether they're good or bad they don't ask; they ask about the money rather than the reputation of the clients' reliability. If someone's poor and not bad, he's considered useless, but if a rich one's bad, he's considered a useful client. People who don't honor the laws or what's fair and good anywhere keep their patrons busy. They deny that what's been given has been given, are full of lawsuits, and are greedy and dishonest men, who have gained their money either on interest or through perjuries. [...] When these men are called to court, their patrons are called to court at the same time since we speak for those who've committed offenses. This is how a certain client kept me very busy today and how I couldn't do what I wanted or who I wanted to do it with, to such an extent did he delay and detain me (LCL 61, 483.485).

The lists of virtues are intended to suggest desirable behaviour. Thus, as G.L. Green ${ }^{21}$ and Peter H. Davids ${ }^{22}$ argue, the fact that faith/faithfulness was given a prominent position in Peter's catalogue of virtues could be understood by the ancient recipients of the letter as emphasising loyalty to a benefactor such as God (1:3-4:11), and a breach of loyalty/faithfulness to a patron would be seen as a moral failing.

This could be the case provided that the narrator of the epistle had adopted the Greek understanding of faith as loyalty. However, as mentioned, his interpretation of this concept is different - egalitarian-donative and existential-practical. ${ }^{23} \mathrm{In}$ the context of the sorites, this last, practical, aspect is especially important. The narrator has already prepared the reader by describing faith-based conduct in devotional-eschatological terms as "all things that pertain to life and godliness" (v. 3a), an "escape from the corruption that is in the world" (v. 4c) "participation in the divine nature" (v. 4b). Thus, one could ultimately define "faith" in 2 Peter as an egalitarian gift ${ }^{24}$ very much tied to the promises of God/Jesus to people. The person of the donor makes the promises credible and their fulfilment certain. One's response to this gift is, in turn, to lead the kind of life to which one has been called and equipped in order to ultimately "partake in the divine nature". In other words, it is on faith that the whole godly life of the faithful rests. It is on the foundation of faith understood in this way, and with its help, that virtue can develop.

21 Green, Jude and 2 Peter, 601.

22 Davids, The Letters of 2 Peter and Jude, 410.

23 Bauckham, Jude, 2 Peter, 185.

24 J. Daryl Charles ("Language," 66) points out that the faith in 2 Peter was not provided ( $\pi a p a \delta i \delta \omega \mu \mathrm{i})$, but

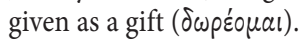




\subsubsection{Virtue}

Like faith, the concept of virtue appears in 2 Peter not only in the sorites. As early as

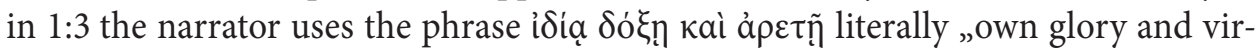
tue" probably taken from Hellenistic literature or created according to models found in Greek texts. Pausanias in his Description of Greece (VIII, 53.6) mentions a statue of Philopoemen at Tegea with an epigram beginning with praise: "The valour and glory of this man [Philopoemen] are famed throughout Greece" (LCL 297, 158-159). In doing so, he uses the expression ả which the second noun modifies the first. Diodorus the Sicilian in his The Library of History (II, 45,2) similarly speaks of "famous virtue" of a certain Amazon ( $\pi \varepsilon p$ à av̀

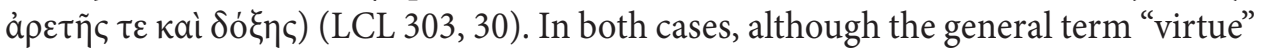
appears, it probably refers to the valour, courage of the heroes praised.

In 1:3 the author of 2 Peter seems to have used an inversion in relation to a phrase

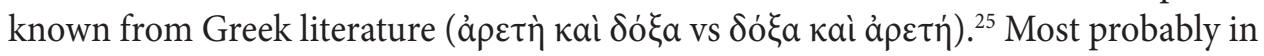
order to avoid too strong an association with philosophy and to give the noun ảperń a slightly different meaning than ethical. ${ }^{26}$ All the more so as he applies this term to God and/or Jesus. The context and the proximity of the noun $\delta$ ó $\xi a$ means that here the term å $\rho \varepsilon \tau \eta \dot{~ i s ~ t o ~ b e ~ u n d e r s t o o d ~ a s ~ p e r f e c t i o n . ~}{ }^{27}$ But the use of inversion also

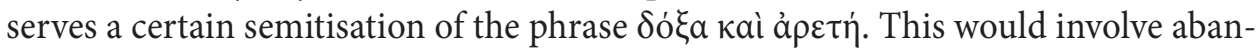
doning the reading of $\delta$ ó $\xi \alpha$ kai a $\rho \varepsilon \tau \eta \dot{~ a s ~ a ~ h e n d i a d y s ~ i . e . ~ " p e r f e c t ~ g l o r y " ~ i n ~ f a v o u r ~ o f ~}$ understanding it in terms of "perfection and glory" - a merism popular in biblical literature. The use of a semitising merism instead of a hendiadis would thus weaken the philosophical-ethical connotations that the notion of à $\rho \varepsilon \tau \dot{r}$ raises.

It is different in 1:5. Here, the narrator places virtue in its philosophical-ethical contexts, primarily because he attributes it to a human. Like the ancient authors, he sees it as a source of behaviour that deserves public recognition and praise (cf. Quintilian, Institutio Oratoria III, 7,15). In that he is not alone. Virtue is also described in this ethical sense in the late, deuterocanonical books of the OT. In Wis 8:7 the list of virtues derived from the love of justice is very reminiscent of the already mentioned list of Hellenistic cardinal virtues: "If a man loves righteousness, the fruits of wisdom's labour are virtues, for she teaches soberness, understanding, righteousness and courage. There is nothing in life more profitable for people then these." In 2 Macc 15:12 the moral aspect of virtues is emphasised; in 3 Macc 6:1 virtue can mean both moral dispositions and actions: "Then Eleazar [...] whose life had been adorned with vir-

\footnotetext{
25 Mickiewicz, List świętego Judy, 226.

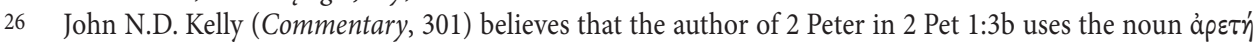
in an ethical sense; otherwise Bauckham (Jude, 2 Peter, 178), who thinks it unlikely that à $\rho \varepsilon \tau \dot{\eta}$ means moral virtue.

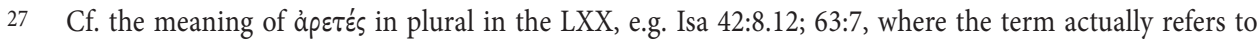

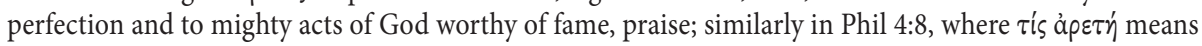
something worthy of praise or fame.
} 
tue"; likewise in 4 Macc 1:10, which commends the virtues of the seven kindred martyrs who suffered death during the Maccabean uprising (167-160 B.C.), and in 4 Macc 13:24 praising the seven brothers "practicing the same virtues, and reared up in a just course of life." In 4 Macc 1:2 "the highest virtue" is identified with self-control. This is accompanied by a philosophical introduction: "For reason is necessary to everyone as a step to science. In addition, it embraces the praise of self-control, the highest virtue"; 4 Macc 1:30 also links virtue and reason in a philosophical way: "For reasoning is the leader of the virtues." It is different in 4 Macc 10:10, where virtue is a divine gift: "We [...] suffer this for the sake of Divine education and virtue."

It seems that the latter meaning and origin of virtue is taken over by the narrator of 2 Peter, and it is mainly this donative character that distinguishes Peter's theological take on virtue from the Greek ethical take. In philosophy, as already noted, virtue is the result of human reflection, the fruit of reason and knowledge, and moral perfection can be achieved by one's own efforts. Peter, however, derives virtue from

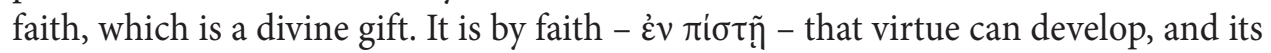
development is not limited to reflection and the cultivation of moral dispositions, but, as with most ancient authors, is directed towards action. Indirectly, therefore, virtue is also to be regarded as a divine gift.

So what happens is a clear theologisation of the philosophical concept of virtue. It develops in two directions. The first, different from Greek philosophy, points to the origin of virtue - it is the result of faith and is based on God's will. The second, assimilative, emphasises its active dimension, since virtue cannot be limited to ethical dispositions and theoretical reflection, but must manifest itself in action, as revealed by the successive links of the sorites - self-control, steadfastness, godliness, brotherly affection and love [of one's neighbour], which has its source in divine love. In this way, virtue becomes the practical aspect of faith.

\subsubsection{Knowledge}

The third link in the sorites is knowledge. In contrast to verses 2 and 3, which also

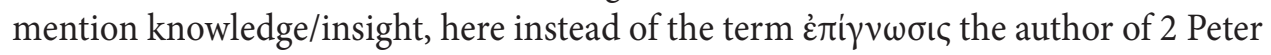
uses the term $\gamma \nu \tilde{\omega} \sigma \iota \varphi^{28}$ The two terms are nearly synonymous, and are generally used synonymously by the narrator, especially in the sorites in 1:5-6 and in v. 8, where, as said, he sarcastically argues against knowledge as a source of virtue. However, it is possible to try to identify some nuances that distinguish them, especially since both occur very close to each other. 'E $\pi$ i $\gamma \nu \omega \sigma \iota c$ implies a certain dynamic, a process of getting to know. The preposition $\dot{\varepsilon} \pi \mathrm{l}$ has either a locative or a temporal meaning; it is often used to indicate continuity in time or space and to intensify a concept, to emphasise concentration, accumulation of certain features. These elements - especially

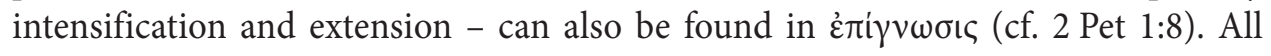

Mickiewicz, List świętego Judy, 227. 
the more so since in the NT the term is often used to describe getting to know the essence of someone or something, the attainment of knowledge by means of insight, recognition, discovery, ${ }^{29}$ acceptance, acknowledgement of something or someone as something or someone (cf. Rom 1:20-21).$^{30}$ It is therefore progressive, dynamic and, what is important, presupposes personal involvement.

The second concept usually refers to knowledge already acquired and is therefore more static, sometimes even definitive. ${ }^{31}$ Obviously, the use of the more static term $\gamma \nu \tilde{\omega} \sigma ı \varsigma$ makes recipients intuitively associate it with familiar ethical systems, whereas the more speculative $\gamma \nu \tilde{\omega} \sigma \iota \varsigma$ was either seen as an end in itself or, as already stated, as the origin and source of the virtues. It could also be the equivalent of mystical union and knowledge of the deity, as in the Orphic or Hermetic systems, and later also the Gnostic ones. ${ }^{32}$ The author of 2 Peter seems to argue against such meanings. Like the Stoics, he juxtaposes knowledge and virtue, showing that he believes in an organic, inseparable relationship between the two, ${ }^{33}$ but presents them in reverse order - as virtue and knowledge. This surprising inversion forces the recipients to revise their belief that virtue is a consequence of knowledge; they must assume that it is knowledge that develops through virtue. And since virtue has practical implications, knowledge too must be seen in practical rather than theoretical terms.

Also important here is the indirect connection between knowledge and faith, from which all other qualities derive. This connection points to the synonymy of

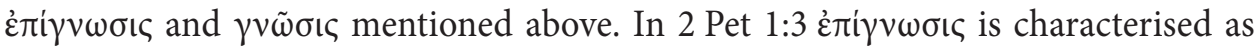

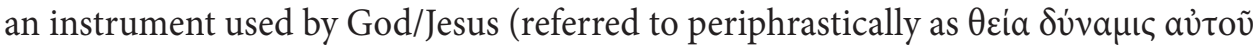
"His divine power"). ${ }^{34}$ This means that knowledge, with all its aspects, is not the fruit of human speculation, effort, inquiry and striving, but a disposition given to Chris-

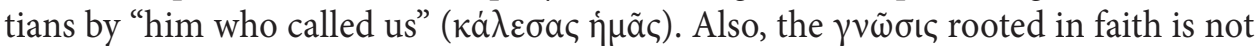
a quality acquired by man through his own efforts and/or reason, but, like faith itself, a gift (cf. Prov 1:7; Jer 1:5) that equips one to lead a godly life.

Hence, if virtue means the practical aspect of faith, i.e. praiseworthy acts resulting from obedience to God's will, then knowledge in this context must mean learning, understanding, and discerning what acts and actions are right or consistent with

29 Robert E. Picirelli ("The Meaning of Epignosis," 89-93) reviews the various positions on this subject.

30 Neyrey, 2 Peter, Jude, 149.

31 It is sometimes claimed that by using these related and very close terms, the narrator of the epistle opposes the teaching of false prophets and teachers. Formerly thought to represent some strand of Gnosticism, today this thesis is abandoned and Peter's opponents are identified as those who, adhering to a far-reaching syncretism, combined elements of Greek philosophy, Greek mythology (cf. 2 Pet 1:16) and the emerging Christian doctrine. See Kelly, Commentary, 299; Green, Jude and 2 Peter, 554.

32 See Corpus Hermeticum XIII, 7-9, where gnosis is understood as a rebirth in God achieved by withdrawing into oneself, putting the senses to sleep, purifying oneself from the twelve mindless torments of the material world; the chain of these torments begins with ignorance. See Mead, Thrice-Greatest Hermes.

33 Charles, "Language," 67.

34 Mickiewicz, List świętego Judy, 218-221. 
God's will (Phil 1:9; cf. Eph 5:17), and constitute a part of leading a godly life. Peter's $\gamma \nu \dot{\sigma} \sigma \varsigma \varsigma$ can thus be seen as a reflection on the meaning of actions, which are not intended to be an end in themselves or a reason for glory and recognition among men, as was the case in the Greco-Roman world, ${ }^{35}$ but are a testimony to faith. In this way, the relationship between faith and knowledge is highlighted, and practically oriented knowledge ceases to be mere intellectual speculation.

By overlaying the meanings of $\dot{\varepsilon} \pi \mid \gamma \nu \omega \sigma \iota \varsigma$, previously defined in Christian terms, and $\gamma v \tilde{\omega} \sigma \iota \varsigma$, associated with philosophy, the narrator of 2 Peter explicitly Christianises the latter. He had previously given the ethical concept of à $\rho \varepsilon \tau \dot{\eta}$ a theological meaning by directly rooting virtue in faith. He also presented faith itself in theological terms, on the one hand, as God's gift and equipment that allows man to lead a pious life, and in practical terms on the other, describing its successive manifestations. In this way he reduced the loyalty-based and juridical understanding of faith characteristic of Greco-Roman literature. It may be noted that the common element here is the redefinition of concepts firmly rooted in Greek ethics by subjecting them to theologisation. This theologisation, in turn, is based on pointing to a different source of the virtues and their meaning than in Greek literature. For the narrator of 2 Peter, all virtues, beginning with faith, are divine gifts and not innate or developed human qualities. Since the process of theologisation of the virtues appears in the reinterpretation of the meanings of the concepts forming the initial links of the sorites, it can be assumed that it will continue in a gradational manner also in the subsequent concepts-links. Gradation in this case means an increasing degree of Christianisation of successive concepts up to agape as summum bonum.

\section{Conclusions}

As can be seen, by using sorites, the narrator of 2 Peter enters into a dialogue with philosophical hypotexts, which were keen to use this rhetorical figure and principle. As noted in the introduction to the article, an interplay or relationship between hypo- and hypertext is one of the conditions of intertextuality, but it must also be accompanied by a distinguishing element.

The dialogue between 2 Pet 1:5-7 and its Greek models takes place on two fundamental levels. The first level applies to composition - the arrangement of links in the chain of virtues. While most ethical catalogues begin with knowledge, reason (or equivalents of these terms), Peter's list opens with faith. Thanks to the fact that it has already been described earlier in the epistle (1:1-2), the narrator can introduce its egalitarian-donative and active understanding into the catalogue he constructs. By doing so, he informs the recipient that the sorites will not list virtues that are the re-

Kelly, Commentary, 306. 
sult of human insight and ability, but those that result from God's endowment. In this way, he also indicates the direction of the reinterpretation of the concepts that make up the sorites - their theologisation.

Thus, the second level of dialogue concerns semantics. The narrator of 2 Peter subjects the individual links of the sorites to a theologising and sometimes even Christianising reinterpretation. This is particularly evident in the links with the concepts of "virtue" and "knowledge," which are among the most fundamental elements of the Greek sorites of an ethical nature. In Peter's perspective, they become a manifestation of faith and acquire a clearer practical aspect, just as the initial mother-link.

Thus, it can be said that in his hypertext the narrator of 2 Peter creatively transforms elements borrowed from hypotexts. The transformations include two types of procedures. The first one involves taking over the traditional form of sorites but changing the combination of links. The second one involves introducing new elements into this form - this can be seen in the final links: brotherly love and love [of one's neighbour], which did not appear in the Greek chains of virtues, and reinterpreting the elements forming the traditional system. ${ }^{36}$ In his typology of intertextual strategies, Stanisław Balbus refers to such procedures as creative continuation. ${ }^{37}$ Peter does not abandon classical rhetorical models; on the contrary, in his adaptation he uses most of their philosophical connotations, yet creatively transforms them in such a way that they can be applied to Christian doctrine (the theoretical aspect related to the origin of virtues as gifts) and conduct (the practical aspect).

\section{Bibliography}

Aristophanes, Frogs. Assemblywomen. Wealth (ed. and trans. J. Henderson) (Loeb Classical Library 180; Cambridge, MA: Harvard University Press 2002) 3-235.

Aristotle, Art of Rhetoric (trans. J.H. Freese; rev. G. Striker) (Loeb Classical Library 193; Cambridge, MA: Harvard University Press 2020).

Balbus, S., Między stylami, 2 ed. (Kraków: Universitas 1996).

Bauckham, R., Jude, 2 Peter (Word Biblical Commentary 50; Waco, TX: Word Books 1983).

Charles, J.D, Virtue Amidst Vice. The Catalog of Virtues in 2 Peter 1 (Journal for the Study of the New Testament Supplement Series 150; Sheffield: Sheffield Academic Press 1997).

Charles, J.D., "The Language and Logic of Virtue in 2 Peter 1,5-7," Bulletin for Biblical Research 8 (1998) 55-73.

Cicero, On the Republic. On the Laws (trans. C.W. Keyes) (Loeb Classical Library 213; Cambridge, MA: Harvard University Press 1928) 289-520.

Danker, F.W., Benefactor. Epigraphic Study of a Graeco-Roman and New Testament Semantic Field (St. Louis, MO: Clayton 1982).

36 Balbus, Między stylami, 128.

37 Balbus, Między stylami, 100. 
Davids, P.H., The Letters of 2 Peter and Jude (Pillar New Testament Commentary; Grand Rapids, MI: Eerdmans 2006).

Diodorus Siculus, Library of History. II. Books 2.35-4.58 (trans. C.H. Oldfather) (Loeb Classical Library 303; Cambridge, MA: Harvard University Press 1935).

Diogenes Laertius, Lives of Eminent Philosophers. I. Books 1-5 (trans. R.D. Hicks) (Loeb Classical Library 184; Cambrigde, MA: Harvard University Press 1925).

Genette, G., Palimpsesty. Literatura drugiego stopnia (trans. T. Stróżyński - A. Milecki) (Gdańsk: Słowo/Obraz Terytoria 2014).

Głowiński, M., „O intertekstualności,” Pamiętnik Literacki 77/4 (1986) 75-100.

Green, G.L., Jude and 2 Peter (Baker Exegetical Commentary on the New Testament; Grand Rapids, MI: Baker Academic 2013).

Gryglewicz, F., „Rozwój teologii Listu św. Judy i Drugiego Listu św. Piotra,” Ruch Biblijny i Liturgiczny 33 (1980) 247-258.

Homer, Iliad. I. Books 1-12 (trans. A.T. Murray; rev. W.F. Wyatt) (Loeb Classical Library 170; Cambridge, MA: Harvard University Press 1924).

Kelly, J.N.D., A Commentary on the Epistles of Peter and of Jude (Black's New Testament Commentary; London: Black 1982).

Korolko, M., Sztuka retoryki (Warszawa: Wiedza Powszechna 1990).

Langkammer, H., „List św. Judy i II List św. Piotra oraz ich znaczenie dla kontynuacji doktryny apostolskiej," Roczniki Teologiczno-Kanoniczne 32/1 (1985) 109-121.

Mead, G.R.S., Thrice-Greatest Hermes. Studies in Hellenistic Theosophy and Gnosis (trans. G.R.S. Mead) (London: Theosophical Publishing Society 1906) II.

Menander Rhetor - Dionysius of Halicarnassus, Menander Rhetor. Dionysius of Halicarnassus, Ars Rhetorica (ed. and trans. W.H. Race) (Loeb Classical Library 539; Cambridge, MA: Harvard University Press 2019).

Mickiewicz, F., List świętego Judy. Drugi List świętego Piotra. Wstęp, przekład z oryginału, komentarz (Nowy Komentarz Biblijny. Nowy Testament 18; Częstochowa: Święty Paweł 2018).

Neyrey, J.H., 2 Peter, Jude. A New Translation with Introduction and Commentary (Anchor Bible 37C; New York: Doubledey 1993).

Pausanias, Description of Greece. IV. Books 8.22-10 (Arcadia, Boeotia, Phocis and Ozolian Locri) (trans. W.H.S. Jones) (Loeb Classical Library 297; Cambridge, MA: Harvard University Press 1935).

Philo, On the Cherubim. The Sacrifices of Abel and Cain. The Worse Attacks the Better. On the Posterity and Exile of Cain. On the Giants (trans. F.H. Colson - G.H. Whitaker) (Loeb Classical Library 227; Cambridge, MA: Harvard University Press 1929).

Picirelli, R.E., “The Meaning of Epignosis," Evangelical Quarterly 47 (1975) 85-93.

Plautus, Casina. The Casket Comedy. Curculio. Epidicus. The Two Menaechmuses (ed. and trans. W. de Melo) (Loeb Classical Library 61; Cambridge, MA: Harvard University Press 2011).

Quintilian, The Orator's Education. II. Book 3-5 (ed. and trans. D.A. Russel) (Loeb Classical Library 125; Cambridge, MA: Harvard University Press 2002).

Rosik, M. - Wróbel, M.S. - Langkammer, H., Komentarz do Listu św. Jakuba Apostoła, 1-2 Listu św. Piotra Apostoła, 1-3 Listu św. Jana Apostoła, Listu św. Judy i Apokalipsy (Komentarz Teologiczno-Pastoralny do Biblii Tysiąclecia. Nowy Testament 5; Poznań: Pallottinum 2015).

Seneca, Epistles. II. Epistles 66-92 (trans. R.M. Gummere) (Loeb Classical Library 76; Cambridge, MA: Harvard University Press 1920). 